$\begin{array}{ll}\text { Variants } & \begin{array}{l}\text { Variants } \\ \text { The Journal of the European Society for Textual } \\ \text { Scholarship }\end{array}\end{array}$

$12-13$ | 2016

Varia

\title{
James Joyce. Ulysses: Based on the 1939 Odyssey Press Edition
}

William S. Brockman

\section{(2) OpenEdition \\ Journals}

\section{Electronic version}

URL: http://journals.openedition.org/variants/399

DOI: 10.4000/variants.399

ISSN: 1879-6095

\section{Publisher}

European Society for Textual Scholarship

\section{Printed version}

Date of publication: 31 December 2016

Number of pages: 263-267

ISSN: 1573-3084

\section{Electronic reference}

William S. Brockman, « James Joyce. Ulysses: Based on the 1939 Odyssey Press Edition », Variants [Online], 12-13 | 2016, Online since 01 May 2017, connection on 23 September 2020. URL : http:// journals.openedition.org/variants/399 ; DOI : https://doi.org/10.4000/variants.399

This text was automatically generated on 23 September 2020 .

The authors 


\title{
James Joyce. Ulysses: Based on the 1939 Odyssey Press Edition
}

\author{
William S. Brockman
}

\section{REFERENCES}

James Joyce. Ulysses: Based on the 1939 Odyssey Press Edition. Revised and corrected edition. Annotated by Sam Slote, Marc A. Mamigonian and John Turner. Richmond: Alma Classics, 2015. xiv, 878 pp. ISBN 978-1-84749-399-6

1 For the last couple of decades, readers of Ulysses seeking an annotated edition have had two choices: The Oxford "World's Classics" facsimile reprint of the first 1922 edition with annotations by Jeri Johnson (1993), and the Penguin "Annotated Students' Edition" based on the 1960 Bodley Head text with annotations by Declan Kiberd (1992). Supplementing these has been Gifford's Ulysses Annotated, a stand-alone and widelyrespected guide. The Alma Press edition (first published in 2012, now out in paperback) offers an option, both in terms of choice of text and philosophy of annotation. Though lacking the wide-ranging introduction of Kiberd and the supplementary textual history of Johnson, it outlines its methodology clearly and holds to it in focusing on annotation in a style that minimizes interpretation but factually and historically situates the novel in the Dublin of 1904.

2 The text is an unexpected choice - the 1939 printing of the Odyssey Press edition of 1932. The move of Joyce's published works into the public domain throughout much of Europe in 2012 made available most English-language versions without regard to copyright restrictions. Thus, Alma Press was able to take advantage of Ulysses's change in status to issue a newly-revived version that otherwise could be found, and only rarely, in used book venues. An offshoot of the Albatross Press, the Odyssey Press was created for the sole purpose of publishing an edition of Ulysses on the continent at a time when British and American publishers, fearing prosecution for obscenity, were reluctant to take it on. The text was set from a later printing of a Shakespeare and 
Company edition, one which had seen some corrections to the admittedly error-ridden first edition of 1922. Alma has reset the original text and made some minor changes in the process, such as using the bold, large-type newspaper style headings in the "Aeolus" episode that appeared in the Shakespeare and Company editions, but were printed as normal text by Odyssey. While this resetting would have been an opportunity to include episode numbers as guideposts through the novel's 552 pages, the lack of these can foster disorientation in a novice reader.

decades the Odyssey Press Ulysses carried the reputation of being "definitive", which derived from the smug statement carried on its initial pages: "The present edition may be regarded as the definitive standard edition, as it has been specially revised, at the author's request, by Stuart Gilbert". Gilbert's involvement was, however, minimal, as he himself was later to acknowledge. Though one could justify the choice of text as being the one issued latest in the author's life, Joyce, in the 1930s involved with the potentially much more profitable American publication of Ulysses, immersed in the completion of Finnegans Wake, and troubled by his daughter's mental health, took no interest in corrections to the Odyssey edition. While the Gabler edition produced a reliable text for the 1980s, the infamous assaults of John Kidd on the edition ensured the continued availability of other more established versions. The Alma text is a valid choice, since it is (with the exception of the Gabler edition now as "standard" as any version of Ulysses could be said to be) probably as or more accurate than other versions of Ulysses sold for years in the English-language markets.

This "revised and corrected" edition of 2015 differs from the 2012 in several ways. First, it adds to Sam Slote's name on the title page the names of Marc A. Mamigonian and John Turner as annotators. The reason for this change is not given, but seems to relate to their involvement as well as Slote's in John Kidd's unfruitful editing of Ulysses in the 1990s; apparently much of that editorial work was carried into the Alma edition of 2012. The text itself has been revised little if at all from 2012, though it has been photographically reduced somewhat. The annotations themselves have been slightly revised and updated.

Keyed to unobtrusive marginal numbers in the pages of the text, notes at the end occupy more than a third of the book. What characterizes them and differentiates them from other annotations is that they are "limited to strictly factual as opposed to interpretive material [. . .]. The goal here has been consistently to provide 'too little': the rationale being that the annotations should not overwhelm the reader's own initiative" (555). An unexpected - and unmentioned - benefit is the inclusion of page and line number references to Hans Walter Gabler's 1986 edition, allowing the Alma Press edition to serve fully as an annotated resource to that version. A notable addition that this 2015 edition makes to the 2012 is the inclusion of material from James Joyce Online Notes, the ongoing venue for annotative research on Joyce, which adds a substantial amount of newly-discovered detail. So, for example, readers of the "Ithaca" episode in the 2015 edition can now enjoy, at least vicariously, the benefits of the "Wonderworker", a previously obscure reference from a flyer in Bloom's drawer (849). The introduction to the 2015 notes includes a paragraph on monetary terminology.

6 The notes do indeed stick to the facts. So, for example, the notes give the address of butcher Dlugacz in "Calypso" but avoid pointing out the irony of a Zionist pork butcher, as do Kiberd, Johnson, and Gifford. Still, the identification of facts can lead the reader astray. For instance, the word "Oot" in "Hades" is not "a call to horses to go 
forward", as Alma notes, but a visual representation of what the men riding in the funeral carriage see before they hear the man on the side of the street calling out his solicitation to sell bootlaces. (599) Alma seems to have omitted some purely factual notes. For instance, Gifford explains "golliwog curls" in "Nausicaa"; the racially prejudicial tone of this hairstyle's name deserves to be seen historically, but isn't noted in Alma. On a more positive note, Alma offers important corrections to Gifford. "Which end is the head", Bloom wonders in "Hades" in regard to the coffin's placement in the funeral ceremony. Alma gets it right: the feet are placed nearest to the altar (although the reverse is true in the case of a priest's funeral). Alma resolves Gifford's hopelessly convoluted explanations of the message on the postcard sent to Dennis Breen, "U. p.: up", with a reference to the Oxford English Dictionary's simple definition of the pronounced spelling of the adverb as meaning something that is over or finished (625).

The Notes also flag some prominent misprints in the edition that were corrected by Gabler. For instance, "frilled beefsteaks" are corrected to "grilled beefsteaks" (604). The unintelligible "sidevalue", seeming to be an obscure horseracing term, is corrected to "side. Value" (824). Yet the 2015 paperback edition introduces an unexplained inconsistency: following Gabler, the 2012 edition noted that the correct reading for "you're a goner" was "you're a doner", substantiated by James Joyce Online Notes, yet the 2015 edition eliminates the correction, instead only offering an unneeded gloss on "goner" (604).

This practice of sticking to facts avoids inserting a number of "spoilers". Ulysses typically offers seemingly confusing or incomplete information whose significance becomes apparent to the reader only much later in the book. So, for example, the identity of, and joke upon the racehorse "Throwaway", initially in "Lotus Eaters", is never divulged in Alma as it is by Kiberd; the edition provides ample information about the Gold Cup race but leaves it up to the reader to wait for further information in the "Cyclops" and "Eumaeus" episodes. Similarly, while Gifford identifies Gerty's "one shortcoming" early in the "Nausicaa" episode as her limp, Alma does not, allowing the reader to discover it along with Bloom later in the episode. Though Gifford, Kiberd, and Johnson warn about the veracity of the list of Molly's "lovers" in the "Ithaca" episode, the Alma edition meticulously cross-references the identification of each but avoids any evaluation of the list's veracity.

Alma's bibliographically detailed glosses to the titles of books in Bloom's library are a tour de force and exemplify the extraordinarily well-researched approach that the annotators have devoted to Ulysses. This is a text of choice for first-time and established readers alike.

\section{BIBLIOGRAPHY}

Gifford, Don, and Robert Seidman. 1988. Ulysses Annotated: Notes for Joyce's Ulysses. $2^{\text {nd }}$ ed. Berkeley: University of California Press. 
Joyce, James. 1986. Ulysses: The Corrected Text. Eds. Hans Walter Gabler, Wolfhard Steppe and Claus Melchior. New York: Random House.

Joyce, James. 1992. Ulysses. Penguin Twentieth-Century Classics. London: Penguin.

Joyce, James. 1993. Ulysses. Ed. Jeri Johnson. Oxford: Oxford University Press.

\section{AUTHORS}

\section{WILLIAM S. BROCKMAN}

William S. Brockman is Paterno Family Librarian for Literature at Pennsylvania State University. Bibliographer for the James Joyce Quarterly since 1990, he has published articles and essays on Joyce and modernist publishing and has lectured on these topics at national and international conferences, workshops, and seminars. Presently he is one of the co-editors of a forthcoming edition of Joyce's unpublished letters. Brockman is a Trustee of the International James Joyce Foundation. 